\title{
BLACK MIRROR AND COVID 19: BIOTECHNOLOGICAL CHALLENGES FOR INTERCULTURAL THINKING
}

\section{Miša Diurković}

Десять лет назад британский журналист и сценарист Чарли Брукер начал создавать сериал «Черное зеркало» как форму современной антиутопии. Особенностью сериала стал акцент на том, что биотехнологические инструменты невероятно увеличивают способность контролировать людей, манипулировать ими и экспериментировать на них. Критика евгеники, трансгуманистической классовой дифференциации, медиа-тоталитаризма, порабощения социальными сетями также была представлена в сериале. Сегодня многие из предсказаний Брукера неожиданно начали сбываться. Пандемия коронавируса открыла пространство для массового использования новых технологий, таких как камеры распознавания лиц 5G, приложения для смартфонов или использование искусственного интеллекта, алгоритмы которого определяют состояние здоровья человека и, соответственно, степень свободы его передвижения. Офицеры с тепловыми забралами, которые появлялись на улицах китайских городов, чтобы опознавать и изолировать людей с повышенной температурой, выглядят так, как будто они только что сошли с подмосток шоу Брукера. Автор статьи стремится продемонстрировать и проанализировать на основе методологии Брукера фундаментальные проблемы свободы, разнообразия и приватности, обусловливающие выживание человека в современном мире. В свете событий пандемии Covid 19 он анализирует современные приемы интерпретации реальности. Делается вывод, что некоторые традиционные православные взгляды и ценности могут способствовать защите человеческого достоинства от трансгуманистических экспериментов и связанной с ними опасности.

Ключевые слова: «Черное зеркало», биотехнология, наблюдение, межкультурное мышление, свобода.

(C) Djurkovic M., 2020
Institute of European Studies, Belgrade

Ten years ago, the British journalist and screenwriter Charlie Brooker began creating the "Black Mirror" TV series as a form of contemporary dystopia. Its characteristic is a special focus on biotechnological instruments that increase the ability to monitor, manipulate and experiment on human beings. The criticism of eugenics, transhumanist class differentiation, media totalitarianism, enslavement to social networks is also featured in the series. Nowadays many of those visions began to appear in reality. The coronavirus pandemic has opened up the space for massive use of new technologies such as $5 \mathrm{G}$ face recognition cameras, smartphone applications, or the use of artificial intelligence whose algorithms determine an individual's health status and degree of freedom of movement. Officers with thermal visors who have appeared on the streets of Chinese cities to identify and isolate people with a high temperature seem as if they have just emerged from Brooker's show. With the addition of previously known social credit experiments in some Chinese cities, we have become aware that the civilization faces one of its greatest possible challenges. In this contribution, the author seeks to demonstrate, on the basis of Brooker's methodology, the fundamental challenges to freedom, independence, diversity and privacy as fundamental phenomena of human survival. Also, in the light of the actualization of these visions in the time of the Covid 19 pandemic, he strives to re-examine the space that contemporary thinking, of various fields and traditions, gains or conquers in the facing and reflecting on reality. He offers some insights into traditional Orthodox views on technology which might contribute to the defence of human dignity from experiments and transhumanistic danger.

Keywords: "Black Mirror", biotechnology, surveillance, intercultural thinking, freedom.

https://doi.org/10.31119/phlog.2020.1.107 
The first episode of the television series Black Mirror, broadcasted in 2011, tells the story of a British prime minister who is forced to have sexual intercourse with a pig in front of the cameras. Four years later, there came out a public testimony about how David Cameron (the prime minister at the time of the broadcast of the mentioned episode) actually had to put his penis into a pig's mouth during his student days when he was initiated into the Piers Gaveston Society. The author of this series, Charlie Brooker, in the book Inside the Black Mirror, claimed [3, p. 43] that he had no previous information about this anecdote, but that unfortunately he was increasingly noticing how his weird ideas about the development of modern society, and above all about the pathology caused by rapid technological progress, appear in reality.

With the emergence of the Covid 19 crisis, as in some science fiction story or mass experiment, modern civilization has transformed overnight in incredible ways. An important part of this transformation which we are witnessing every day is the massive use of technology, gadgets, applications, virtual reality, CCTV, 5G face recognition technology, drones, and thermal visors used by the police, and all forms of surveillance of people. The dystopia announced by Brooker during the past decade suddenly started rapidly realizing in front of our eyes.

In this article, we will first discuss the phenomenon of the Black Mirror series, which has become one of the symbolic pillars of modern culture, not unlike Fritz Lang's Metropolis or Orwell's 1984. Black Mirror, and its opening with a broken black screen, became a metaphor for the justified fear increasingly felt by the more enlightened parts of humanity due to the environment growingly surrounded by technology, the radically increased dependence on it and especially the more and more pronounced forms of pathology and the real dangers it allows.

In the second part of the article, we will focus on the still current events surrounding the coronavirus pandemic. In the interest of tackling this infection, hundreds of millions of people have been placed under surveillance, locked down and isolated. During the pandemic, an increasing number of countries, whether nominally authoritarian or liberal-democratic, began to use hitherto unimaginable amounts of technological control, surveillance, networking, data processing, and other forms of techno-management that directly violate privacy and basic human rights. Fear for security is used as a legitimization of extremely dangerous practices, and as Snowden [18] points out, we know from previous experience that governments will find it difficult to give up these mechanisms even after the end of the epidemic.

If we take into account the ideas of large corporate magnates (Bill Gates, for example), who are working hard to develop vaccines, with the idea of making them mandatory and potentially containing nanoparticles that allow monitoring of the internal state of the human body, with data sent to computers and networks, and the idea of vaccination passports as a condition for any trip to other countries, then the fears justifiably increase.

Viewed from that perspective, we will finally try to analyse the challenges that the development of biotechnology and surveilled societies brings 
to humanity and see how interculturally conceived and applied thinking can react to it.

$* * *$

In the modern world, in which the phenomena of popular culture gain instant popularity and subsequently disappear overnight, it is still possible to notice an extraordinary work of art that stands out in its genre and defines one area, despite the fact that we are overwhelmed with novelties. That is exactly what happened with the British television series Black Mirror. The project, which was launched by the talented and experienced screenwriter, television figure and author Charlie Brooker in 2011 with only three episodes, has become one of the most important artefacts of modern civilization in less than ten years. So far, in five seasons of broadcasting, with one Christmas special and one feature-length interactive film, 22 episodes have been realized. This series, in which each segment is made as a supreme combination of aesthetics, philosophy and ethical issues, and in which everything from lighting to music, acting and camera plays an important role, created a special world and marked an entire genre. Today, without referring to the series it is almost impossible to seriously explore the position of modern technology, its rapid progress and the consequences it brings to human societies, institutions, practices, relationships and human self-perception ${ }^{1}$. This also refers to any consideration of the fundamental, basic human identity, which develops in the series starting from a small "cookie" in which the consciousness of an individual is replicated, through cyborgs to holograms.

It is interesting to note that the first season of the series was broadcast in 2011 , exactly two centuries after the appearance of the so-called Luddite movement in England. Even before them, there were important intellectual challenges to the modern fascination and belief in natural science and technology as universal panaceas for the progress of the human race - the third part of Swift's saga that leads Gulliver to Laputa and Balnibarbi is still an unsurpassed, witty and sharp critique of mathematisation and scientism. But the Luddites, followers of the fictional leader "General Ned Ludd", were the first organized practical group to recognize the direct and imminent danger to themselves and their families in machines and technology. From their perspective, the advancement of machinery did not lead to universal progress or a utopia, but to the abolition of jobs and the reduction of wages, that is, to misery and enslavement. They therefore broke and destroyed machines and defined the technology itself as a problem. ${ }^{2}$

\footnotetext{
${ }^{1}$ At the protests against Trump's presidential election, a banner was seen that reads: "This episode of Black Mirror sucks" [16].

${ }^{2}$ With the rapid advancement of robotics, artificial intelligence and other forms of technology that make dystopian scenarios of human redundancy and replacement by machines increasingly relevant, interest and respect has risen for "General Ludd" and his notorious movement against whom the British authorities passed a special law in 1812, and sent an army to defend the factories from them [5]. At the dawn of the computer age
} 
Brooker started his project as a distant reflection of the Luddite spirit. As he explains the incentives that led him to create the series, around 2010 a new wave of techno-optimism, fascination with the iPhone and increasingly numerous smart gadgets began to redefine our workspace, perceptions, habits, desires, forms of entertainment, and even our love and sex life. Suddenly, we willingly or unwillingly become surrounded by screens on all sides, and our every step or act, as Snowden quickly taught us, has become available to secret services, corporations, or private hacker and criminal groups that can play with us and blackmail us. The title of the series and its fantastic opening sequence, which with a frightening psychotic sound theme and rising tensions leads to the cracking of a seemingly empty black mirror, have become a metaphor for dystopia, and all the numerous dangers of this screened world in which "privacy is no longer the norm". ${ }^{1}$

The Black Mirror is a series conceived as an echo of the famous Twilight Zone (1959-1964). It revived the form in which each episode tells a stand-alone story with new actors. But in addition to form, it is connected to the Twilight Zone by its willingness to deal with fantastic, sometimes paranormal phenomena, and the way in which these things affect human relationships. Black Mirror is especially interested in the novelties that technology enables and its consequences on human life and human societies.

Already in the first two seasons (with three episodes each), it achieved great success and won a special place with a refined, educated audience, but also with the wider masses who love gadgetry and fiction. But when Netflix joined the project in December 2014, the series gained an incredible momentum. The audience expanded, primarily in the USA, but also in other parts of the world; better and more expensive production was enabled, as well as the engagement of A-list stars such as Jody Foster, actors from the series Med Men, Breaking Bad, House of Cards etc. Filming in Iceland and other attractive locations also became possible. The third and fourth seasons with six episodes each, as well as the interactive film from 2018 , were met with an extraordinary reception, while preserving originality, inventiveness and a high level of criticism towards the topics brought by modern gadget culture.

The series has won a number of Emmy awards and other recognitions, but it has also been taken very seriously by theorists in the field of social sciences. So far, as many as four books dealing with this phenomenon have appeared. In addition to the useful bedecker Inside Black Mirror, in which Brooker and Annabel Jones, in conversation with Jason Arnopp and other protagonists, revive topics and present production data, Black Mirror and Critical Media Theory [4], Black Mirror and Philosophy [10] (Blackwell), and Through the Black Mirror [11] (Palgrave Macmillan) have been published. The latter two were done as individual analyses of each episode of the

in 1984, the American writer Thomas Pynchon wondered if it might be okay to be a Luddite.

${ }^{1}$ This is exactly what Mark Zuckerberg said during his Senate hearing in 2010, when he answered the question why the profile on Facebook was open and not closed by default. 
series and the theoretical problem it deals with. In addition, a large number of articles have been published, even in other languages (Spanish, Russian) ${ }^{1}$.

One of the important metaphors that Brooker uses is that modern technology is not unlike narcotics in that it causes various forms of addiction, and that the series explores the side effects of that pathology [2]. It has long been noticed that due to using smartphones or the Internet people today memorize less and less, relying on the complete externalization of data, counting on the fact that all data, including important phone numbers, will always be available to them via computers and gadgets. Children spend their time less and less socializing and playing outside with friends, and more and more in their rooms, through the interface (games, consoles, social networks), etc.

The second level of narration is the question of how technology (re)shapes the universe of human discourse and action [13]. Corporations, governments, hackers, individuals can manipulate and shape our desires, needs, habits, ways of looking at the world, communicating with other people, loving, hating, imagining, participating or not participating in politics, social life, etc. The process of our subjectivization and bildung today is deeply impregnated and conditioned by the network of technology in which we move and on which we depend for performing daily tasks, work, entertainment, and even choosing friends or partners ${ }^{2}$.

Brooker deliberately placed the episodes in a time that is just a little ahead of ours [12, p. 10]. The technology used in the episodes, which often serves as the basis of the plot, is already in the realm of the conceivable, and as we will see, some of these ideas have already been realized in just ten years since the series began broadcasting. Thus, the effect of the series and the questions it raises is further strengthened because it directs us to a world in which we will live very soon, and instead of resolution and harmony, we usually get very dangerous indications. Technology, which should be a form of prosthetics for us, something that strengthens and expands our possibilities and helps us, becomes the most common source of worries, anxiety, addiction, and human suffering.

In a manifest text written for The Guardian [2], announcing the start of the broadcast of the series, Brooker explained that the Black Mirror is placed between the pleasure that each of us gets from the screen and worrying about where it all leads. The key is that it is first necessary to understand how the world is changing rapidly due to technology: "We routinely do things that just five years ago would scarcely have made sense to us. We tweet along to reality shows; we share videos of strangers dropping cats in bins; we dance in front of Xboxes that can see us, and judge us, and find us

${ }^{1}$ At the University of Amsterdam, Professor M. Baerveldt teaches a special course called Black Mirror, our human condition in a digitalised society (https://www.uva.nl/ en/programmes/open-programmes-iis/black-mirror/black-mirror.html).

2 Paul Virilio and Baudrillard are thinkers who have been systematically following this transformation for several decades. Virilio published his important work on Speed and Politics in 1977 [25], and in 1999 he released the Information Bomb [24], which is very relevant to what Brooker is doing. 
sorely lacking. It's hard to think of a single human function that technology hasn't somehow altered, apart perhaps from burping. That's pretty much all we have left. Just yesterday I read a news story about a new video game installed above urinals to stop patrons getting bored: you control it by sloshing your urine stream left and right. Read that back to yourself and ask if you live in a sane society."

\section{$* * *$}

In order to capture the range of techno-social challenges, we will try to briefly present the basic topics and problems that have been covered in the series from the beginning. In the first season, the authors dealt with the terror of social networks, the perverted idea of engaged artistic performance, the problems of mass surveillance, the hypertrophied culture of screens with games, reality shows, avatars, with unlimited pornography and the terror of entertainment (a world in which one loses credit if $\mathrm{s} /$ he refuses to watch pornography and partake in entertainment), as well as transhumanist ideas about expanding human memory, mutual surveillance and control that causes an obsession with the past and re-examination.

The second season brought, first of all, playing with the possibilities of artificial intelligence and augmented reality (the idea of reconstructing a person based on the data she left about herself on social networks), as well as with the figure of a cyborg. This was followed by a realistic dystopia about the possibilities of a new system of punishment - a corporate park of justice that includes reality shows, theatre and repetitive psychological torture of prisoners. It ended with the idea of the participation of an animated character in the parliamentary elections, the destructive role of social networks and the mixing of entertainment and politics, with a clear indication of the role of secret services in manipulating technology, social networks and even politics. Another addition was a Christmas special that also brings three important stories: a Bluetooth device with conference training in sex coaching, then doubling and transferring a person's consciousness to a small egg (cookie), from where she leads the whole household like an Alexa device, and finally a new criminal investigation system based on manipulating the consciousness of such a separated suspect, and playing with the possibilities of a person being darkened, excluded and erased in reality (such as rejection on social networks or a legal restraining order).

The third season has fantastically expanded the existing range of issues, adding new ones to those already underway. It started with the treatment of the so-called "social credit" system, the idea that, as on social networks or websites such as Booking, Tripadvisor, etc., people are constantly evaluating and rating each other on a scale of one to five, and that their employment, rent, financial credibility, possibility of movement and use of other social services and amenities depend on one's average rating. Then we had the analysis of the corporate video game system with the idea of using living people as guinea pigs, but also augmented reality and neuro-analysis with torture performed on us by machines. What followed was a monstrous episode dedicated to hacker monitoring of people's behaviour on the Internet, blackmail, incitement to crime and destruction of their lives by disclos- 
ing surveilled actions. The next episode deals with the possibility of virtual life through avatars and the creation of parallel virtual worlds, with the possibility of transferring one's consciousness to a hard disk, i.e. to the software of some of these permanent virtual adventures. The fifth episode touches on the controversial fields of eugenics and chipping - soldiers who have implanted chips get a distorted perception of certain dehumanized classes of people in order to eliminate and remove them more easily, without remorse. The last episode is about bee-shaped minidrones, which are produced for human needs, and end up as alleged mass murderers of hundreds of thousands of people who were targeted on social networks, from the person who incited their malice and eventually punished them.

The fourth season brings new kinds of modern technology, putting them in logical but controversial contexts. The series opens with a story about a video game creator who, with the help of the DNA of his colleagues from the same company, creates a parallel world in which he can harass, dominate and abuse them. What follows is a variation on different forms of parental supervision (surveillance) over children, through the story of an embedded chip through which a mother can look from a distance through her daughter's eyes, always locate it precisely and censor phenomena that a girl should not see (blood, violence, sex). The next story is about the massive covering of public and private space with mini cameras, grains, drones, and what a police investigation and the behaviour of people in such a world looks like. In the fourth episode, Brooker plays with a variation of Tinder and other dating apps used today, exposing them as a simulation. The following is a story about robots, automated, military machines that have autonomy to choose the ways of realizing their given goal of eliminating people. Finally, there is a three-part episode in which the idea of a device for causing pain addiction is put forth, then the idea of the consciousness of a deceased woman which her husband transfers to his head, and another variation on the idea of corporate punishment - people with holograms of convicts that visitors can endlessly torture.

The interactive film from 2018 played with the idea of an interactive computer game in which the player chooses actions and directions, so that in the meantime, virtual and real realities are shifted. The narration about the games also appears in the first episode of the fifth series, in which players can fight via avatars, but also make love with real stimuli (similar to the Matrix movie). This is followed by a story about dysfunction and tragedies that cause addiction to smartphones and social networks, and finally an examination of the mechanisms that the corporate industry uses or will be able to use (psycho-drugs, tranquilizers, holograms) in the production, control and exploitation of teenage slaves in the music industry.

This last episode brought the series its first big music hit, a cover of the song On a Roll performed by “Ashley O” (played by Miley Cyrus) with about 20 million views on YouTube so far. This reinforced the very widespread thesis $[16 ; 13 ; 12$, p. $42 ; 29$, p. 56] about the controversy of the capitalist world in which we live, where such a rebellion against technology and corporatism eventually comes to be treated as a commodity, a form of goods, just like any other product that can be well cashed in. The series is sup- 
ported by Netflix as a leading corporate player in the age of media digitization, the most important promoter of new digital platforms that make cable TV and previous generations of technologies obsolete ${ }^{1}$.

$* * *$

It has long ago been noticed that various controversial ideas, gadgets and technological possibilities, used in the Black Mirror as fiction, very quickly found application in reality or accounts surfaced that work was being done somewhere on their realization. There are numerous examples, including the notorious social credit system that several cities in China are already experimenting with, then multi-purpose mini drones like bees from the episode Hated in the Nation, even something like a grain used as an externalizer of our memory, etc. ${ }^{2}$

But events during the coronavirus pandemic have shed additional light on the controversies and problems that Brooker has opened [6]. This pandemic will be remembered as the first crisis in which the tools facilitated by the new digital technological revolution were used en masse in controlling the infection, but were also introduced into the general social and political system, with a great likelihood of becoming a permanent setting of our lives and universally applicable.

The first thing we have learned from the wars and great crises of the last century is that once they have seized new and expanded powers, as a rule governments do not intend to give them up completely when the crises pass. At the moment, this primarily refers to mass electronic surveillance, which, along with the pandemic, is spreading around the world, both in China and in Britain, for example. This crisis will be remembered in history as the first case of mass use of all forms of new technologies, from robots,

${ }^{1}$ Already after the fourth season, which was otherwise well received, there were criticisms that Brooker had become repetitive and that the basic ideas were mostly repeated, with a predictable resolution (https://www.engadget.com/2018-01-04-blackmirror-season-four.html). One can hardly agree with this statement, but the assessment that the fifth season has nothing more to say does not seem unfounded (https://www.engadget. com/2019-06-11-black-mirror-season-five-review.html). Video games, social networks, obsession with controlling children, are really already exhausted topics, so only the last episode tackled a new topic, but with a lot of mannerism and unreality in the implementation. Whatever the future of this project may be, what has been done so far is more than enough.

${ }^{2}$ Blackwell reports that there has been a patent for a device such as a grain since 2003, and that Sony recently patented a device based on smart eye lenses that have the ability to record. There are also a number of other gadgets (GoPro, Google glasses, etc.) that have similar features, except that they are not implanted [1]. Troullinou and D'Aquinn covered three episodes (Be Right Back, Entire History of You, Hated in the Nation), showing that for all three cases (personality reconstruction with the aid of artificial intelligence, grain and mini drones) there are already similar patents, products and potentials to introduce almost identical gadgets into mass practice [20]. For an expert analysis of the possibility of creating similar technology, see [7]. 
through virtual reality, to numerous instruments for monitoring and tracking people, using their private data almost without any restrictions.

A special problem is that the countries that violated the rights of their citizens proved the most successful in fighting the crisis. China, South Korea, Singapore, but also Israel, have shown excellent results in controlling and combating the spread of Covid 19, as well as a small number of casualties. But the methods they use are gaining Orwellian proportions. China has cameras installed in front of the apartments of those in isolation, barcodes on phones determine people's health status, cameras with 5G technology and face recognition also monitor movement and hunt the disobedient, artificial intelligence algorithms in the "WeChat" application define recommendations for the duration of isolation and (non)restricted movement. From the beginning of April 2020, police officers with special visors that can recognize faces, identify persons and register fever among the observed people are on the streets. Chinese officials claim that these cameras, which send real-time data to the headquarters, i.e. to the police database, help to identify criminals and terrorists, but from recent times also people who have a fever. Such a person stands out in red (as in the White Christmas episode) and is led to triage and examination.

In Singapore, the "TraceTogether" application is used, which registers possible contacts of infected people with other people via a Bluetooth signal between smart phones. In South Korea, a combination of data on the use of credit cards, the location of smartphones, camera recordings, as well as monitored conversations of people, is used to make a publicly available map of the movements of the infected. In Israel, the secret service monitors the movements of those who should be in quarantine over the phone. In Poland, the infected have the obligation to install an application through which the police check whether they are in quarantine. Both Germany and France, among others, have announced the mandatory introduction of an application that pings on a smartphone if you approach someone less than a meter away. There are ideas to introduce this throughout the European Union.

Bulgaria and the United Arab Emirates have used drones to fight the pandemic. The Bulgarians equipped the drones with thermal cameras and set them to fly over Roma settlements and thus check whether there were any hotspots with high temperatures. In the Emirates, drones with face recognition cameras were used during lockdown to identify those moving through the streets without permission, and then the authorities sent fines to their home address. In Singapore, at the beginning of May, they also introduced a four-legged robot dog called Spot with a camera that walks around the park and monitors how many people there are and how much they adhere to the obligation of wearing a mask, keeping distance, etc. This data is reviewed by the competent service that controls it remotely. Journalists have noticed that the robot in question was almost identical to the one from the Metalhead episode of the Black Mirror ${ }^{1}$, which is understandable because it was made by the company Boston Dynamics, whose prototypes Brooker and his team used to develop theirs.

\footnotetext{
${ }^{1}$ https://www.marca.com/en/lifestyle/2020/05/09/5eb7224122601d35418b4633.html.
} 
However, what causes most concern and has even triggered large protests in a number of countries (USA, Germany, Poland) is a topic that, surprisingly, Brooker has not dealt with yet - compulsory vaccination. Vaccination is becoming one of the biggest bioethical and, above all, biopolitical problems in the world today, causing huge controversies and seemingly justified fears among ordinary people. Huge corporations such as Novartis, GlaxoSmithKline or Microsoft (Melinda and Bill Gates Foundation), which are the largest financiers of the World Health Organization, have established a strong political and media lobbying system that introduces mandatory vaccination against a growing number of "potential diseases" in an increasing number of countries. People are threatened with financial penalties, having their children taken away from them, bans on enrolling children in schools and kindergartens, etc. For those public figures, doctors and thinkers who express concern and have a critical attitude towards the controversial, violent spread of this practice, the mocking name antivaxers was coined, while those who point to the greed of corporations and opportunities for them to profit at the cost of our health are called conspiracy theorists ${ }^{1}$.

During the crisis, this lobby was extremely vocal in promoting a culture of vaccination as mandatory for the future world. They focused on two points. One is developing a vaccine against SARS-CoV-2. Bill Gates has said that as many as seven of his factories are working in that field, and over 8.7 billion euros were collected at a pledging conference. A number of actors mentioned the possibility of using nanochips as part of the vaccine, which would send (somewhere? to someone?) data on the state of a given organism $^{2}$.

The second point is the mandatory status of this vaccine, which would be provided by the so-called obligatory vaccination health passports, and those would, in turn, be a prerequisite for movement, travel and sports competition. On May 5, the state of Serbia introduced a new protocol which, in the wake of these recommendations, radically tightened its policy towards vaccination to worrying proportions. The obligation to have all available vaccines has become a condition for enrolling children in school under the threat of having them taken away them from their parents. Tennis player Novak Djokovic's public scepticism towards the use of a potential vaccine that has not yet even been invented has caused a barrage of accusations and defamation ${ }^{3}$.

In the end, thanks to the efficiency that China has allegedly shown in the fight against Covid 19 owing to the use of technology, its soft power has

${ }^{1}$ Even great philosophical names like Giorgio Agamben, who during the corona crisis expressed reservations about the behavior of states, international institutions and corporations, were ostracized and ridiculed [22].

${ }^{2}$ This was seen in the last episode of the James Bond franchise, the movie Spectre, ("smart blood") as a model for the permanent tracking of a disobedient agent.

${ }^{3}$ It is very easy to forget that after the Second World War, precisely because of Nazi biopolitics and experiments on humans, the rule was introduced that no substance can be injected into people without their consent [26]. In contrast, mandatory vaccination is being pushed everywhere today. 
grown tremendously globally, especially in Europe. The people of Italy are infinitely grateful for their help, as in Serbia, and many other countries would gladly accept their help and experience. But, as many times before in history, questions arise as to whether the people of Europe are ready to accept the suppression of their freedom and privacy, and full control over their bodies for the sake of efficiency and security.

There is a justified fear that many states, but also corporations and renegade parts of the state administration, will continue to use the mechanisms of monitoring and tracking people even after the corona crisis, and to abuse them for various illegal things. The Black Mirror taught us in a great way what dangers and possibilities of abuse are hidden behind all this fascination with the new technology introduced for security reasons. To paraphrase Brooker, we will only hear about the dark sides of these novelties.

$$
* * *
$$

The Black Mirror is an attempt to face the challenges of (bio) technologies that originated at the very centre of modern Western and corporate culture. The noble attempt of intercultural philosophy is based on the affirmation of other traditions, so it is very interesting to see how other traditions have faced the challenges of technology, how they do it today, and whether something can be learned from those perspectives.

For example, the living Islamic practice in the Muslim world limits excessive interest rates as haram and has led to the important practice of $\mathrm{Mu}$ hammad Yunus with micro-credits. Due to this living religious and moral practice, there are restrictions on financial machinations in Muslim countries, which have much fewer problems with the banking system. As we know, it has now become a regular periodic phenomenon in the West.

Before the outbreak of the corona crisis the University of Tübingen planned to hold a summer school of intercultural philosophy with Professor Yuk Hui, entitled "Philosophies of Technology in an Intercultural Perspective" ${ }^{1}$. In his 2016 book Question Concerning Technology in China, professor Hui tried to develop an authentic perspective called "cosmotechnics", which he provisionally outlines as "the unification between the cosmic order and the moral order through technical activities" [9].

This is very interesting because it seems that the modern Chinese civilization is becoming a leader in the Faustian brutal use of technology in the name of profit, in which there is no room for ecology, ethical boundaries, respect for intellectual property, rule of law, etc. China is becoming a leading technological giant, but without the barriers of the rule of law, democracy, respect for individual human rights and similar restrictions that prevent corporations in the Western world from turning human society and nature into nothing more than "resources" for profit. Contrary to the hopes of much of the world that it could balance Western fascination with profit, development, and bare materialism, modern China seems to have become hyperwestern and hypermaterialist, marked by the worship of profit, tech-

1 See http://www.edu-active.com/camps/2020/mar/17/summer-school-philosophiestechnology-intercultura.html. 
nology, and materialism. Hence the great fears of reports about the cloning of macaque monkeys, experiments with genetically modified twins, the fact that China is slowly becoming a leading force in cashless payments and especially regarding all these above-mentioned uses of digital technologies for human surveillance and control.

Most of the attempts of other cultures to confront (Western) technology have so far moved mainly between the thesis that it goes with the acceptance of complete Western metaphysics, culture and political institutions, and other views, as a rule utopian, that Western technology can simply be superimposed onto a mostly intact authentic spiritual, the cultural, religious or political tradition of a people.

In the last thirty years since Eastern European countries came out of communism, and Orthodoxy began to return to the public sphere, debates have begun within the Orthodox world about the attitude towards technology and the customs that its accelerated progress brings. A large part of the population in Orthodox countries today behaves, thinks and values the world according to the same customs used and followed by the majority of the Western world. But at least a part of the population, led by the clergy and some intellectuals, journalists, and rarely politicians, tries to rethink the essence of the technique from the perspective of its tradition. Here, at the end, we will present some of those views, demands and actions to determine the position of the Orthodox world on this progress in technology.

The great Serbian theologian Nikolaj Velimirović summed up the essence of the Orthodox view of technology in the following way: "Technology is deaf, mute, and unanswering. It is completely dependent on ethics, as ethics on faith" [23]. Velimirović reminds us that technology has been present among humans since their inception, but that there has always been the question of how it will be used, and that depended on the value and ethical assumptions that man accepts.

Orthodoxy, similarly to the logic with which Jacques Maritain defended the idea of human rights and the Universal Declaration of Human Rights after the Second World War, also believes that the establishment of value frameworks stems from transcendence and faith. Thus, that intersubjectivity is not a sufficient guarantor or protector of the norms on the inviolability of the human being as an image of God, and that only faith can sanctify and establish universal ethical norms. The Nazi experience for Orthodox thinkers reinforced the significance of Dostoevsky's thesis from the novel The Brothers Karamazov "If there is no God, then everything is allowed."

If we take the figure of a hacker as a metaphor for all the problems that an individual can cause, we will understand that the challenge of modern technology is more dangerous than the great threat of a nuclear war had been in the Cold War. At that time, the points of a potential threat were located very precisely; they were centralized and easier to monitor and control. Today's challenges are capillary, they spread like the Internet through billions of homes, and hence states may find it harder to locate sources of threat and prevent them from doing harm. On the one hand, corporations have the means and ability to manipulate various areas of technological advancement, but on the other hand, a talented individual can go much far- 
ther with knowing computer software, using software shortcuts so as to endanger banks, individuals and institutions, and breach their security systems. When we look at the capillary expansion of the space for threats and challenges, it is understandable that sometimes it looks as if only prayer can give us some hope...

With the rapid development of biotechnology in recent decades, bioethical issues are increasingly coming into the focus of Orthodox thinkers, reinforcing the need to recall Dostoevsky's dictum. Everything that is possible must not be allowed, the modern formulation would say. But as Gayle Woloschak [27] noted, the different nature of the Orthodox world, unlike the centralized Catholic Church, has led to a lack of universally shared attitudes of Orthodoxy towards modern technology. Patristic thinkers, of course, could not give instructions for a world of computers and biotechnology, so today Orthodox thinkers face these problems in different ways: from a certain techno-optimism espoused, for example, by Woloschak herself to the extremely negative attitudes that can be found in the more conservative parts of the intellectual and public community ${ }^{1}$. But here we will stick to the official attempts of the churches to determine their positions on the issues of technological challenges.

In the first attempt of an Orthodox church to explain the basis of its social teaching, there is a special chapter dedicated to bioethical topics [19]. In it, the church, starting from the Holy Scriptures, the Holy Fathers' tradition and the great Russian Orthodox thinkers, tries to set limits for the possibility of biotechnological intervention in the nature of man, conception, death and family. The basic idea is about the sanctity of the human person, as an image of God, which has dignity and thus limits the legitimacy of experimentation. Based on it, a clear borderline is set between what is acceptable when it comes to medical interventions and what is not and must never be. While accepting the possibility of insemination and IVF, the church precisely insists on the unacceptability of destroying embryos or using them for therapeutic purposes. The church also points out the dangers of abusing prenatal testing, opposes the idea of human cloning and surrogacy, and accepts organ transplantation only as voluntary and non-commercial. A special problem that it envisaged 20 years ago is the Nietzschean idea of transhumanism and human enhancement.

Therefore, in this area as well, the church repeats the necessity of setting limits on the use and abuse of technology, insisting that decisions on limits are ethical, value-based and, from its perspective, religious. Technology will not set limits for itself or limit its future evolution. This must be done by people, preventing the interests of irresponsible individuals or corporate actors from crossing those borders through corruption, abuse and illegitimate means ${ }^{2}$.

\footnotetext{
${ }^{1}$ For example, see [17] on Russian neoconservative thinkers.

${ }^{2}$ Western science and philosophy continue to operate largely with the implicit acceptance of the idea of progress based on the advancement of the natural sciences and technology. The Russian Orthodox philosophical tradition has long rejected the progressive discourse.
} 
The authors also deal with the issue of science and the relationship between man and technology in Chapter 14. Here, too, they point to the erroneous assumptions of the Enlightenment that produced scientism and fascination with science divorced from value. Therefore, to ensure normal human life it is necessary today as never before to restore the lost link of scientific knowledge with the religious spiritual and moral values, they claim. Modern environmental problems are seen as one of the many indicators of this misconception about free science and technology. "Today's achievements in various fields, including the physics of fundamental particles, chemistry and microbiology, show that they are essentially a double-edged sword that can both benefit man and take away his life. The evangelical norms of life make it possible to educate a person in such a way that the knowledge and abilities acquired could not be abused." The church therefore seeks the return of transcendence and spirituality to education, to public and media space, in order to restore moral, spiritual, value, but also legal limits to the possibilities of technology abuse.

This corpus of principles, which was published in 2000, represents living matter, which is further developing, trying to find its way into the system of legislation, education, and medical practice. But it is built on the rich Russian tradition of Orthodox thinkers and philosophers such as Berdyaev, Solovyov, Sergei Bulgakov ${ }^{1}$ and Ivan Ilyin, who built an authentic, transcendence-based view of man's relationship with technology, science, nature and culture. This corpus of thought, a great body of work created in the diaspora, the so-called "White Russian emigration", has not yet been fully reintegrated into the topology of thought and education in Russia itself, and the central currents of Western philosophy generally do not know or ignore this tradition. It is precisely the issues of technology, the tremendous progress of artificial intelligence and the phenomena discussed in The Black Mirror, that could increase the need to discover this direction of thinking and acting.

In addition to the Russian tradition, let us mention here the Greek Orthodox thinkers, who are primarily engaged in seeking answers to bioethical questions. The work of Metropolitan Nicholas Hadzinikolaou, who has been leading the Synodal Committee for Bioethics of the Archbishopric of Athens since 1998, is especially important. He is the author of the great book Free from the Genome, in which he elaborates the Orthodox position on the issues of genetic engineering, cloning, embryos, assisted reproduction, hybrid experiments on humans, transfusion, organ transplantation and the issue of cremation [30].

Contemporary Western philosophy keeps moving further and further away from transcendence and classical ethics based on it, but also further and further in the direction of detabooing man and what can be done with or to him. The deeply anti-humanist $A$ Cyborg Manifesto by Donna Haraway [8] is one of the most respected and cited publications in modern Western

${ }^{1}$ Some basic outlines of their thought can be found in the articles $[21 ; 28]$ published in a special issue of the journal Condordia, presenting Contemporary Philosophy from Eastern Europe (guest editor: Bianca Boteva-Richter). 
universities... The Orthodox tradition and Orthodox philosophy claim, however, that there can be no return of ethics, values and taboos without a revival of the living religious tradition and transcendence. This perspective in the dialogue with our Western interlocutors such as Heidegger, Levinas or Maritain could help us defend the dignity and inviolability of the human being and set limits to the possibilities of technological experimentation, however seductive, tempting and promising they might seem, especially when it comes to military needs to improve the psychophysical characteristics of $\operatorname{man}^{1}$.

\section{References}

1. Blackwell, D.R. (2018), All Eyes on Me, in: Cirucci, A., and Vacker, B. (eds.), Black Mirror and Critical Media Theory, Lexington Books.

2. Brooker, C. (2011), The Dark Side of Our Gadget Addiction, in: The Guardian, 01. 12, URL: https://www.theguardian.com/technology/2011/dec/01/charlie-brookerdark-side-gadget-addiction-black-mirror.

3. Brooker, C., Jones, A., and Arnopp, J. (2018), Inside Black Mirror, Crown Archetype.

4. Cirucci, A., and Vacker, B.(eds.) (2018), Black Mirror and Critical Media Theory, Lexington Books.

5. Conniff, R. (2011), What the Luddities Really Fought for, in: Smithsonian Magazine, March.

6. Crispin, J. (2020), Yes, I Know We are Living in a Black Mirror Episode. I Still want dystopian TV though, in: The Guardian, 11.05, URL: https://www.theguardian.com/ commentisfree/2020/may/11/black-mirror-episode-dystopian-tv.

7. Epstein, A., and Murphy, M. (2017), How realistic is the futuristic technology in "Black Mirror"?, in: Quartz Daily Brief, URL: https://qz.com/quartzy/1168163/ black-mirror-tech-review-how-realistic-is-the-technology-in-black-mirror-season-4

8. Haraway, D. (1991), A Cyborg Manifesto: Science, Technology, and Socialist-Feminism in the Late Twentieth Century, in: Simians, Cyborgs and Women: The Reinvention of Nature, Routledge.

9. Hui, Y. (2016), Question Concerning Technology in China, Urbanomic.

10. Johnson, D.K. (ed.) (2019), Black Mirror and Philosophy: Dark Reflections, Wiley Blackwell.

11. Joy, S., and McSweeney, T. (eds.) (2019), Through the Black Mirror: Reflections on the 'Side Effects' of the Digital Age, London, Palgrave Macmillan Ltd.

12. Masny, M. (2015), It's not a technological problem we have, it's a human one: Black Mirror and its distopyian narrative on technology, social media, surveillance

${ }^{1}$ The fact that both the allies and the Nazis drugged their soldiers during the Second World War in order to enable them greater endurance, abstaining from sleeping for days, and the like, is just slowly beginning to seep into the public and the media. The Nazis first tested amphetamine and methamphetamine (the drug Pervitin) in concentration camps, and then gave it to their soldiers, in submarines and to pilots, for example [15]. It is hard to think about all the possibilities that armies have at their disposal today for such "enhancements". The Men Against Fire episode deals precisely with that problem. 
and technobody, Master Thesis, University of Amsterdam, URL: https://scripties. uba.uva.nl/search?id=570052

13. Murray, T. (2013), Black Mirror Reflections, in Philosophy Now, URL: https://philosophynow.org/issues/97/Black_Mirror_Reflections.

14. Pochemu serial "Chernoye Zerkalo" schitayut kul'tovym? [Why is the series "Black Mirror" considered a cult?], in: Mnogo smysla [A lot of sense], URL: https://mnogosmysla.ru/smysl-seriala/pochemu-serial-chernoe-zerkalo-schitajut-kultovym.

15. Rasmussen, N. (2011), Medical science and the military: the Allies' use of amphetamine during World War II, in: Journal of Interdisciplinary History, 42, no. 2, pp. 205-233.

16. Sculos, B.W. (2017), Screen Saviour: How Black Mirror Reflects the Present More than the Future, in: Class, Race and Corporate Power, vol. 5, no. 1.

17. Skladanowski, M. (2019), The Devil in Technologies, in: Zygon, Journal of Religion and Science, no. 54/1, pp. 46-65.

18. Snowden, E. Shelter in Place, URL: https:/www.vice.com/en_us/article/bvge5q/ snowden-warns-governments-are-using-coronavirus-to-build-the-architecture-ofoppression.

19. The Basis of the Social Concept (2020), in: The Russian Orthodox Church. Department for External Church Relations. URL: https://mospat.ru/en/documents/socialconcepts.

20. Troullinou, D’Aquinn (2018), in: Cirucci, A., and Vacker, B. (eds.), Black Mirror and Critical Media Theory, Lexington Books.

21. Tsvyk, I.V. (2018), Die Idee des Guten in der Philosphie Wladimir S. Solowjows, in: Concordia, no. 73, pp. 99-108.

22. Van den Berge, L. (2020), Biopolitics and the Corona Virus: in Defense of Giorgio Agamben, URL: http://blog.montaignecentre.com/index.php/2467/biopolitics-andthe-coronavirus-in-defence-of-giorgio-agamben-2.

23. Velimirović, N. (2014), Ethics and technology, in: Orthodox Christian Information Center, URL: http://orthodoxinfo.com/praxis/ethics_and_technology.aspx.

24. Virilio, P. (2006), Information Bomb, Verso.

25. Virilio, P. (2006), Speed and Politics, Semiotexte.

26. Weindling, P. (2014), Victims and Survivors of Nazi Human Experiments, Bloomsbury.

27. Woloschak, G. (2018), Faith, Science, Mystery, Sebastian Orthodox Press.

28. Zamaleev, A. (2018), Die russische Philosophie im post-klassischen Zeitalter, in: Concordia, no. 73. pp. 85-98.

29. Žižek, S. (1999), Bauk i dalje kruži, in: Reč, no. 56. 2, Belgrad, pp. 53-59.

30. Хаџиниколау, Н. (2014), Слободни од генома, Задужбина Каленић. 